\begin{tabular}{lcr}
\hline \multicolumn{1}{c}{ A N N A L E S } \\
UNIVERSitatis & MARIAE CURIE-SKŁODOWSKA \\
LUBLIN - POLONIA & 2020 \\
\hline
\end{tabular}

Uniwersytet Jana Kochanowskiego, Instytut Stosunków Międzynarodowych i Polityk Publicznych

\author{
TOMASZ GAJEWSKI
}

ORCID ID: 0000-0003-1556-1591

\title{
Druk 3D jako technologia zakłócająca $w$ systemie międzynarodowym
}

3Dd Printing as a Disruptive Technology in the International System

\begin{abstract}
ABSTRAKT
Szybki rozwój technologiczny ostatnich lat w coraz większym stopniu definiuje przestrzeń, w której funkcjonują jednostki, społeczeństwa i państwa. Tempo tego procesu jest wysokie, czego konsekwencją są trudności w społecznej absorbcji jego już widocznych efektów oraz niepewność co do charakteru ich wpływu na życie w przyszłości. Jednym z owoców postępu jest technologia druku 3D. Celem niniejszej analizy jest zarysowanie skutków, jakie jej szybki rozwój może wywrzeć w przyszłości na system międzynarodowy.

Analizę otwiera krótkie wprowadzenie do badanego zagadnienia, uzupełnione o przegląd najważniejszych publikacji na ten temat. Następnie autor charakteryzuje metodologię, stawia hipotezy oraz niezbędne do ich weryfikacji pytania badawcze. Część ta zawiera także refleksję nad prognozowaniem w nauce o stosunkach międzynarodowych. Kolejna zawiera najważniejsze z punktu widzenia wywodu pojęcia oraz ich definicje. Następnie autor przechodzi do weryfikacji postawionych hipotez, analizując ekonomiczne konsekwencje rozwoju druku 3D oraz jego wpływ na strukturę konfliktów międzynarodowych, przez co tworzy obraz prognozowanych konsekwencji tego procesu dla funkcjonowania systemu międzynarodowego.
\end{abstract}

Słowa kluczowe: druk 3D, system międzynarodowy, technologia zakłócająca, prognozowanie międzynarodowe, gospodarka światowa, bezpieczeństwo międzynarodowe

\section{WSTĘP}

Skok technologiczny ostatnich lat nie ma precedensu w historii ludzkości. Jego wytwory znajdują swoje zastosowanie we wszystkich obszarach aktywności człowieka. Najbardziej zauważalny jest rozwój technologii informacyjnych, które wywołały 
fundamentalne zmiany w modelach komunikacyjnych i w konsekwencji w zachowaniach społecznych [Nowina Konopka 2017: 24-31]. Osiągnięcia w dziedzinie robotyki wspierają medycynę oraz procesy produkcyjne. Inżynieria genetyczna osiąga coraz wyższe stadia rozwoju. Mniej dostrzegalne w codziennym życiu są nanotechnologia oraz sztuczna inteligencja ${ }^{1}$ czy samouczenie maszyn (machine learning). Konsekwencją tych wielu współistniejących procesów jest postępująca transformacja stylów życia.

Postęp technologiczny jest tak szybki, że zdolność społecznej absorbcji jego efektów nie jest w stanie za nim nadążyć. W świetle tego swoistego ,szoku szybkości” bardzo wymowne stają się słynne słowa Carla Sagana: „Żyjemy w społeczeństwie fundamentalnie uzależnionym od nauki i technologii, w którym mało kto ma jakiekolwiek pojęcie o nauce i technologii. To prosta recepta na katastrofę" [James 2014: 182]. Świat, w którym przyszło funkcjonować społeczeństwom, jest w dużym stopniu niezrozumiały, a jego działanie wyznacza, według Ulricha Becka [2008: 5], oczekiwanie globalnych katastrof. Niemiecki socjolog dowodził, że jest to efektem samego postępu, którego skutkiem ubocznym jest stałe rozszerzanie się katalogu ryzyk. Ich kontrolowanie przestało być możliwe. Analizując ryzyka współczesności, U. Beck (2012: 20) zdefiniował wiele ich cech, w tym delokalizację czasową i społeczną. Delokalizacja czasowa odnosi się do długiego okresu latencji wielu zagrożeń. Społeczną natomiast charakteryzują się ryzyka współczesności jako elementy składowe wielokrotnie złożonych procesów, co czyni ich przyczyny oraz konsekwencje niemal niemożliwymi do rozpoznania. Co więcej, ryzyka uchodzą za niekalkulowalne - niezwykle trudne staje się więc zbudowanie kompletnego obrazu ich struktury.

Wymienione wyżej przeszkody w identyfikowaniu negatywnych trendów rozwojowych są wskazówką czy wręcz nakazem dla podjęcia działań prognostycznych, dzięki którym, po raz kolejny przywołując U. Becka [2012: 23], „uobecniając, inscenizując” ryzyka, „przyszłość katastrofy staje się teraźniejszością - często po to, by odwrócić bieg wydarzeń dzięki wpływaniu na podejmowane aktualnie decyzje". Autor idzie dalej, proponując „uwolnienie fantazji niebezpieczeństw”, by lepiej się przygotować lub w wariancie najbardziej optymistycznym - zapobiec im.

Technologią, która choć znajduje się daleko od najwyżej zaawansowanych faz rozwojowych, a która jest oceniana jako potencjalnie niebezpieczna dla światowej stabilności, jest druk 3D. Nie oznacza to, że jej rozwój może być postrzegany wyłącznie w kategoriach negatywnych. Jej zastosowania otwierają pole do usprawnień w wielu obszarach życia. Należy jednak podejmować próby odczytania negatywnych konsekwencji, jakie dynamiczny rozwój druku 3D może przynieść dla całego świata. Jest to szczególnie istotne, zwłaszcza w kontekście tektonicznych zmian zachodzących w architekturze systemu międzynarodowego. Wyznaczają je nie tylko regres

1 Choć ta już od kilku lat funkcjonuje w powszechnym użytkowaniu w takich dziedzinach, jak choćby telefonia komórkowa [Agomouh 2018]. 
Zachodu, utożsamiany ze schyłkiem globalnej potęgi Stanów Zjednoczonych Ameryki, kryzysem Unii Europejskiej oraz dynamicznym wzrostem siły Chin. Na proces ten składa się wiele procesów społecznych, ekonomicznych oraz technologicznych. Trajektoria tych zmian jest cały czas badana, a ich ostateczne rezultaty pozostają niewiadomą, dodając kolejny element niepewności, tak obecnej we współczesnym świecie [Gruszko, Gajewski 2018: 188-196]. Druk 3D jako istotny element procesu zmian technologicznych jest w tym świetle bardzo ważnym obszarem badawczym.

Technologia druku 3D jest szeroko analizowana przez przedstawicieli nauk technicznych, także w polskim piśmiennictwie naukowym ${ }^{2}$. Na polskim rynku naukowym brakuje jednak refleksji nad wpływem rozwoju druku 3D na szerokie spektrum spraw społecznych. Lukę tę w pewnym stopniu zapełniają prace dziennikarskie oraz artykuły popularnonaukowe, publikowane przez media tradycyjne i wyspecjalizowane portale internetowe ${ }^{3}$. Na język polski przetłumaczono także wiele wartościowych publikacji anglojęzycznych, dotyczących rozwoju technologicznego jako takiego ${ }^{4}$.

Baza zagranicznych publikacji naukowych oraz artykułów w renomowanych periodykach jest bardzo szeroka i cały czas rośnie. Nie sposób wymienić tu wszystkich pozycji. Na wyodrębnienie zasługują analizy naukowe całego procesu szybkich zmian technologicznych ${ }^{5}$. W zagranicznym piśmiennictwie naukowym można także znaleźć publikacje dotyczące wyłącznie technologii drukowania przestrzennego ${ }^{6} . \mathrm{Na}$ uwagę zasługuje także bogaty zasób analiz publikowanych w międzynarodowych czasopismach naukowych ${ }^{7}$. Tworząc artykuł, autor dysponował szerokim dostępem do wielu z nich, przez co niezbędna była staranna ich selekcja.

2 Wśród nich najważniejsze miejsce zajmują pozycje opisujące samą technologię, takie jak: [Czerwiński, Czerwiński 2015;Siemiński, Budzik 2015]. Naukowe analizy tej technologii publikowane są także w branżowych czasopismach: „Acta Bio-Optica et Informatica Medica. Inżynieria Biomedyczna”, „Edukacja-Technika-Informatyka”, „Logistyka”, „Mechanik”, „Pomiary Automatyka Robotyka”, „Problemy Techniki Uzbrojenia”, „Przegląd Spawalnictwa”, „Przestrzeń i Forma”, „Przetwórstwo Tworzyw”.

3 Wśród wielu z nich można wymienić magazyny „Focus” $\mathrm{i}$ „Forbes” oraz portale „Centrum Druku 3D”, „Computer World”, „Cyberdefence24”, „Gazeta.pl Next”, „PC World”, „Singularity.pl”, „Spider's Web”, „WNP.pl”.

4 W tym m.in.: [Cukier, Mayer-Schonberger 2017; Domingos 2016; Gleick 2018; Harrari 2018; Latiff 2018; Kaku 2011; Kaku 2014; O'Neill 2018; Walsh 2018].

5 W tym m.in.: [Alpaydin 2016; Bostrom 2016; Costandi 2016; Culey 2018; D'Aveni 2018; Design Anthropological... 2016; Ford 2016; Greengard 2015; Hornick 2015; Hanson 2008; Jordan 2016; Kozubek 2018; Kurzweil 2006, Parrington 2016; Pasquale 2016; Payne 2018; Paus 2018; Ross 2017; Ruppel Shell 2018; Schwab 2016; Shanahan 2015; Sharre 2018; Skilton, Hovsepian 2017; Springer 2018; Tegmark 2017].

6 Zob. [André 2018; Barnatt 2013; Daly 2017; Gibson, Rosen, Stucker 2015; Hornick 2015; Lipson, Kurman 2013; Rundle 2014; The Decentralized and Networked... 2016].

7 Źródła te można, stosując oczywiście pewne uproszczenie, podzielić na dwie części. Tytuły ukazujące się w pierwszej odnoszą się do technologii jako takiej (wśród nich: "Acta Biomaterialia", "Additive Manufacturing”, "Advanced Functional Materials”, „Biomaterials”, "International Journal of Advanced Manufacturing Technology", "Journal of Materials Processing Technology", "Journal of Mechanical Design", "Journal of Micromechanics \& Microengineering", "Materials \& Design", "Materials Science and Engineering", "Procedia Manufacturing", "Rapid Prototyping Journal", "Tech Directions") oraz do wielowymiarowych konsekwencji jej rozwoju (np: "Journal of Evolution and Technology", "Journal of Futures Studies: Epistemology, Methods, Applied and A lternative Futures", "World Future Review: A Journal of Strategic Foresight", "World Futures: 
Niniejsza analiza została podzielona na pięć części merytorycznych. Otwiera ją charakterystyka aparatu metodologicznego oraz przedstawienie hipotez i niezbędnych do ich weryfikacji pytań badawczych. W części następnej wprowadzone i zdefiniowane zostają kluczowe z punktu widzenia wywodu pojęcia. Właściwą analizę rozpocznie sekcja poświęcona rozwojowi technologii druku 3D, umieszczonemu w szerszym kontekście struktury gospodarki światowej, rozbudowana o próbę zarysowania potencjalnych skutków rozwoju technologii druku przestrzennego dla państw rozwijających się. Następnie autor dokonuje przeglądu możliwości wykorzystania druku 3D przez podmioty niepaństwowe, przede wszystkim organizacje terrorystyczne oraz zorganizowane grupy przestępcze oraz syntetycznie przedstawia kierunki wpływu jego rozwoju rozpowszechnienia na strukturę i charakter konfliktów międzynarodowych. Wnioski z refleksji składają się na próbę prognozy wpływu druku 3D na architekturę systemu międzynarodowego.

\section{METODOLOGIA I ZAŁOŻENIA BADAWCZE}

W przypadku tak zarysowanego problemu badawczego należy zastosować narzędzia z szeroko rozumianego obszaru prognozowania międzynarodowego. Druk 3D choć relatywnie rozwinięty - w sensie technologicznym nie jest jednak powszechny. W dzisiejszym stadium nie jest więc w stanie zadziałać jako technologia zakłócająca działanie systemu międzynarodowego. Perspektywa jej rozwoju nakazuje jednak obserwatorowi wziąć pod uwagę wariant, w którym w fazie umasowienia negatywnie oddziałuje na jego działanie, wymusza modyfikacje wzorców interakcji, działań, przetwarzając tym samym jego strukturę. Technologie addytywne są nośnikiem poważnego potencjału rozwojowego. Już teraz można je więc określić jako słaby sygnał zmian w systemie międzynarodowym i stwierdzić wyłanianie się technologii zakłócającej, która wpłynie nie tylko na swój macierzysty rynek, ale wywoła także szersze konsekwencje, które w warunkach skomplikowanej złożoności systemu międzynarodowego wygeneruje zmiany $\mathrm{w}$ jego strukturze.

W jaki jednak sposób, posługując się metodą naukową, tworzyć sądy na temat wydarzeń tak odległych od punktu w czasie, w którym znajduje się badacz? Instrumentarium dostarcza prognozowanie międzynarodowe, które od końca zimnej wojny zyskuje coraz większe znaczenie w nauce o stosunkach międzynarodowych i szerzej w naukach politycznych [Łoś-Nowak 1993: 155]. Prognozowanie, choć często uznawane za pozbawione waloru naukowości, posiada jednak narzędzia metodologiczne. Andrzej Chodubski [2009: 46] podkreślił ścisły związek prognozowania z analizą pewnej rzeczywistości. Elementami budującymi takiego procesu analitycznego są

The Journal of New Paradigm Research”, „European Journal of Futures Research”, “Foresight: The Journal of Future Studies, Strategic Thinking and Policy”, „Futures”, ,International Journal of Forecasting”, , Journal of Forecasting”, „Technological Forecasting \& Social Change”). 
przede wszystkim identyfikowanie wyłaniających się i rozpoznanych już trajektorii rozwoju sytuacji międzynarodowej oraz ,ujawnianie zarysowujących się i występujących prawidłowości rozwoju; ustalenie istotnych czynników jakościowych, kształtujących prawidłowości rozwoju stosunków międzynarodowych; oszacowania warunków i założeń dalszego rozwoju; formułowanie odważnych zarazem realnych do urzeczywistniania celów przyszłościowych”. A. Chodubski postulował przy tym, by prognozy dokonywane na podstawie takich wytycznych były możliwie jak najbardziej kompleksowe, biorące pod uwagę całość parametrów, zjawisk i zależności oraz różnego rodzaju sprzężeń. Prognozowanie międzynarodowe sprowadza się do racjonalnego rozumowania, redukcji nieprawności, „ograniczonej i zdyscyplinowanej spekulacji” oraz „eksplorowania nieznanego” [Choucry 1974: 63]. Ostatecznym rezultatem prognozowania nie jest jednoznacznie trafna predykcja przyszłości. Według A. Karpińskiego, najważniejszym efektem tworzenia prognoz jest wywołanie zmian w postawach ludzkich [Karpiński 2009: 35].

Jorgen Randers [2014: 30], określając prognozę domniemywaniem opartym o rzetelną wiedzę, zwrócił uwagę na niemożliwy do przewidzenia czynnik zmian ludzkiej woli i niespodziewanych decyzji, które w nieokreślonym momencie mogą przetworzyć cały (w świetle niniejszej analizy - międzynarodowy) system. Zasadne jest więc „wyobrażanie”, „tworzenie” przyszłości. Pionier holografii, Denis Gabor, pisał wręcz o tworzeniu ich od podstaw [Gabor 1964: 161]. Ma to szczególne zastosowanie w przypadku prognoz ostrzegawczych [Kozub 2013: 102]. Negatywne prognozy, idąc za U. Beckiem, stanowią metodę , uobecniania ryzyka”. W jaki jednak sposób tworzyć naukowo poprawne prognozy?

Jednym z podstawowych narzędzi prognozowania jest ekstrapolacja, która według A. Chodubskiego [2009: 47] ,służy nade wszystko do opracowania prognoz ostrzegawczych do ujawniania możliwości scenariuszy zdarzeń, zjawisk w stosunkach międzynarodowych”. Ekstrapolacja to „wnioskowanie o tendencjach rozwojowych, stosunkach, warunkach, wartościach (zwłaszcza funkcji matematycznych) na zewnątrz jakiegoś przedziału na podstawie znanych, zaobserwowanych tendencji, wartości, itp. wewnątrz niego".

Błażej Sajduk [2009: 2] zwrócił uwagę na rosnący poziom zastosowania metod heurystycznych w prognozowaniu, kojarzonym przede wszystkim z naukami ekonomicznymi. Instrumenty heurystyczne są łatwiejsze do wykorzystania w stosunkach międzynarodowych. Obserwuje się także wyraźny trend w naukach zajmujących się antycypowaniem rozwoju wydarzeń, które w coraz większym stopniu posługują się wyobraźnią.

Prognozowanie to także poszukiwanie układów odniesienia w przeszłości. W swych zasadach efektywnego prognozowania Paul Saffo [2007: 129] zachęcił do „spoglądania w przeszłość dwa razy dalej niż spogląda się w przyszłość" (Look Back Twice as Far as You Look Forward). Saffo argumentował także, by badacz-prognosta precyzyjnie wskazywał granice obszaru niepewności, by był świadomy najważniejszych niewiadomych i nie mnożył alternatyw. Istotne jest także to, by badacz dostrzegał i przykła- 
dał odpowiednią uwagę do „rzeczy, które nie pasują”, a więc zdefiniowanych wyżej słabych sygnałów. P. Saffo [2007: 130-131] zaapelował także o pokorę i ostrożność w prognozowaniu, stwierdzając, że należy wiedzieć, kiedy nie należy prognozować.

Istotną kwestią jest horyzont czasowy prognozy. Prognoza krótkoterminowa, jak powszechnie przyjęto, obejmuje roczny horyzont czasowy. Średnioterminowa od 2 do 5 lat, dhugoterminowa 10 do 20 i perspektywiczna 30 do 50 lat [Sułek 2010: 64]. Istotnym elementem prognoz charakteryzujących się najdłuższym horyzontem (strategicznych), co jest szczególnie istotne z punktu widzenia prognozowania wpływu technologii addytywnych na system międzynarodowy, są, jak stwierdził A. Chodubski [2009: 53], „wskazania normatywne, obejmujące przede wszystkim sferę podmiotową stosunków międzynarodowych oraz ewolucję zachodzących wśród niej relacji. Prognozy te stosuje się współcześnie zwłaszcza do sfery urzeczywistniania wartości globalnych”. Prognozy o charakterze strategicznym stosuje się, według Mirosława Sułka [2010: 64], jako instrument wsparcia procesu podejmowania długofalowych decyzji, tworzący „,szeroką bazę informacyjną, na którą składają się informacje z różnych źródeł o wysokim stopniu przetworzenia”. Ma to szczególne zastosowania w przypadku prognozowania zmian w systemach międzynarodowych wywołanych presją rozwoju technologii druku 3D, które będą wypadkową czynników ekonomicznych oraz wywołanych przez nie transformacji społecznych, politycznych, a być może także geopolitycznych (zgodnie z mechanizmami działania technologii zakłócających poziomu drugiego).

Prognozowanie rezultatów oddziaływania czynników, w obecnej chwili określanych jako słabe sygnały, może zostać wzbogacone o teorię chaosu deterministycznego. Jako teoria powstała na gruncie nauk ścisłych jest trudna do zastosowania w naukach społecznych. Postuluje się jednak jej wykorzystanie jako modelu teoretycznego bez komponentu matematycznego. Istotą jej przydatności jest obrazowe ukazanie działania układów/systemów nieliniowych, których cechą konstytutywną jest wrażliwość na warunki początkowe (tzw. efekt motyla). Teoria chaosu powstała na gruncie meteorologii, w ramach której podejmuje się próby prognozowania jednego z najbardziej nieliniowych układów - atmosfery. Twórcą tej kategorii był amerykański meteorolog i matematyk Edward Lorenz. Jak wythumaczył to James Gleick [2018: 37]: „W nauce jak w życiu: dobrze wiadomo, że łańcuch zdarzeń może mieć punkt krytyczny, który mógłby zwielokrotniać małe zmiany. Ale chaos oznaczał, że takie punkty były wszędzie. One się rozprzestrzeniały. W układach takich jak pogoda wrażliwość na warunki początkowe jest nieuniknioną konsekwencją sposobu, w jaki małe skale przeplatają się z wielkimi”. Niewielka fluktuacja na jego peryferiach może wywołać masowe zmiany w jego przyszłym zachowaniu. System międzynarodowy także jest wielokrotnie złożonym układem, charakteryzującym się nieliniowością i podatnością na warunki początkowe ${ }^{8}$. Jest on układem chaotycznym. Należy w tym miejscu rozróżnić

\footnotetext{
8 Obrazowym tego przykładem może być akt samospalenia, którego w 2010 roku dokonał w Tunezji Mohamed Bouazizi. Wydarzenie to określa się jako wyzwalacz reakcji łańcuchowej, w czasie której do rewolucji dochodziło w kolejnych państwach regionu Bliskiego Wschodu i Afryki Północnej. To z kolei
} 
podkreślaną przez neorealistów i kojarzoną niekiedy z chaosem anarchię, czyli brak podmiotu porządkującego system międzynarodowy [Waltz 2010: 93-94] od chaosu, który definiują nieciągłość oraz generowana przez działanie tzw. dziwnego atraktora nieprzewidywalność. Jego obecność sprawia, że ruch całego układu może niespodziewanie zmienić trajektorię. Dylan Kissane [2007: 92-93] stwierdził, że w chaosie w systemie międzynarodowym, w przeciwieństwie do anarchii, „wszyscy sprawują kontrolę $\mathrm{i}-\mathrm{w}$ efekcie - nikt jej nie sprawuje". Chaos ten jest jednak deterministyczny, układ zmierza więc w kierunku odzyskania jakiejś formy stabilności. Ta nie musi oznaczać przywrócenia poprzednich jego parametrów, a stanowi dostosowanie się do nowych warunków [McIntyre 2013: 105-108].

Rozpatrywanie systemu międzynarodowego jako dynamicznego układu nieliniowego [Jervis 1997: 34], skrajnie nieprzewidywalnego (mimo długookresowego dążenia do stabilności) i stosowanie teorii chaosu służy podkreśleniu zmian, jakie mogą wywołać fluktuacje w jego, z pozoru niewiele znaczących, elementach. Uwypukla to rolę nie tylko podmiotów niepaństwowych lub w skrajnych przypadkach nawet jednostek, ale także trendów technologicznych, których najczęściej nie analizuje się z punktu widzenia potencjału wywołania szerokich zmian, a jedynie modyfikacji sytuacji na właściwym im rynku.

Prognozowanie w naukach społecznych jest oczywiście obciążone różnymi wadami, na co zwraca uwagę Charles F. Doran [1999: 12-15]. Wyróżnia on trzy podstawowe typy prognoz w naukach społecznych. Pierwsza, kompletna, zawiera odpowiedzi na pytania: „co się wydarzy?”; „kiedy do tego dojdzie?”. Dwa pozostałe, to prognozy mniej uszczegółowione. W prognozie alfa zawarte są odpowiedzi na pytania „co się wydarzy?” i „kiedy to nastąpi”. Prognoza typu beta zawiera jedynie odpowiedź na pytanie „co się wydarzy”.

W przypadku prognozowania oddziaływania wpływu rozwoju technologii addytywnych na system międzynarodowy należy przyjąć możliwie najdłuższy horyzont czasowy. To z kolei oznacza, że prognoza nie będzie kompletna w rozumieniu przywoływanego C.F. Dorana. Będzie prognozą typu beta, ze względu na niezwykłą trudność we wskazaniu konkretnego przedziału czasu, bez uciekania się do spekulacji, co wiąże się z opisaną wyżej świadomością chaotyczności systemu międzynarodowego. Będzie to prognoza ostrzegawcza ze względu na podkreślenie negatywnych skutków jej rozwoju. Jej walorem jest postulowanie przez U. Becka „uobecniania ryzyka” i tym samym kolejny przyczynek do dyskusji nad ewentualnym przygotowaniem się na okoliczność szybkiego rozwoju tej technologii ${ }^{9}$.

\footnotetext{
wywołało turbulencje w całym systemie międzynarodowym - wojna domowa w Syrii dała początek procesowi redystrybucji siły i przypieczętowała koniec Pax Americana w regionie; skutkiem wojny w Syrii oraz Libii (która przyczyniła się do wybuchu wojny w Mali) była fala uchodźców, która wygenerowała wielkoskalowy kryzys w Unii Europejskiej i przyczyniła się do faktycznego zahamowania procesu integracji oraz wzrostu siły populizmu. To jedynie reprezentacja skutków tzw. Arabskiej Wiosny.

9 Niezwykle interesujące są dyskusje nad ewentualnym skonstruowaniem bariery w rozwoju technologicznym, by nie zagroził on światu (na pierwsze miejsce wysuwa się tu kwestia sztucznej inteligencji).
} 
Rozważania nad tak postawionym problemem badawczym przy użyciu zaprezentowanego wyżej instrumentarium metodologicznego zostaną oparte na następujących hipotezach badawczych:

1. Rozpowszechnienie technologii druku 3D zmieni strukturę światowej gospodarki.

2. Rozwój druku 3D wpłynie na strukturę konfliktów w obrębie systemu międzynarodowego.

W konsekwencji należy podjąć próbę odpowiedzi na następujące pytania:

1. Jakie zmiany w strukturze światowej gospodarki może wywołać rozwój technologii druku 3D?

2. W jaki sposób druk 3D wpłynie na stabilność państw rozwijających się?

3. W jaki sposób druk 3D wpłynie na funkcjonowanie odwołujących się do przemocy aktorów niepaństwowych?

4. W jaki sposób druk 3D zmodyfikuje działania państw w sytuacjach konfliktowych?

By prawidłowo przeprowadzić tak skonstruowany wywód, należy zidentyfikować i zdefiniować podstawowe z jego punktu widzenia pojęcia.

\section{SIATKA POJĘCIOWA}

Autor przyjmuje, że najbardziej istotne dla analizy będą następujące kategorie: czwarta rewolucja przemysłowa; system międzynarodowy; technologie addytywne; druk 3D; technologia zakłócająca; podmioty niepaństwowe; słabe sygnały.

Siłą sprawczą, która wyznacza bieg wydarzeń we współczesnym świecie, nadaje tempo wielu procesom politycznym, społecznym i ekonomicznym, jest tzw. czwarta rewolucja przemysłowa. Termin ten ma swoje źródła w koncepcyjnym dokumencie rządu Republiki Federalnej Niemiec, dotyczącym wysokich technologii, który został przedstawiony na targach w Hanowerze w 2011 roku [Schlak 2015]. Według założyciela i szefa Światowego Forum Ekonomicznego, Klausa Schwaba, czwarta rewolucja przemysłowa jest definiowana przez rozwój m.in. sztucznej inteligencji, robotyki, internetu rzeczy, autonomicznych pojazdów, druku 3D, nanotechnologii, komputerów kwantowych. W konsekwencji, jak argumentował K. Schwab [2016: 1-3], mamy do czynienia z głębokimi przemianami w strukturach wszystkich przemysłów, symbolizowanymi przez ,pojawienie się nowych modeli biznesowych, zakłóceniami już funkcjonujących, przekształceniami mechanizmów produkcji, konsumpcji i systemów transportowych". Na płaszczyźnie społecznej trwające przemiany wpływają na to, w jaki sposób przebiega praca, komunikacja i ekspresja, informowanie i rozrywka. Nie ulega wątpliwości, że w związku z przytoczonymi wyżej szybkimi zmianami ma miejsce redefinicja i „uczasowienie” pojęć, a także pojawienie się zupełnie nowych, za pomocą których opisuje się otaczający świat. Odpowiada to skalą przeobrażeniu związanemu z rewolucją przemysłową XIX 
wieku, które Reinhart Koselleck nazywa „czasem siodła” [Osterhammel 2013: 84]. W związku z zakresem zachodzących procesów obiektem ich oddziaływania jest także szeroko rozumiany system międzynarodowy.

Ze względu na wielość definicji systemu międzynarodowego, różne sposoby jego postrzegania i umiejscawiania $\mathrm{w}$ różnych paradygmatach teoretycznych, autor przyjął podejście charakteryzujące się największą pojemnością i potencjałem eksplanacyjnym. System międzynarodowy, definiowany przez George'a Modelskiego [cyt. za: Łoś-Nowak 2006: 135] to „system społeczny, charakteryzujący się właściwymi sobie strukturalnymi i funkcjonalnymi mechanizmami działania, który tworzą elementy, interakcje między nimi oraz ich atrybutami [...] system odzwierciedla charakterystyczne wzorce działań i oddziaływań tworzących go elementów". System międzynarodowy, będący przedmiotem badania, będzie rozpatrywany jako kategoria ontologiczna.

Technologie addytywne polegają na łączeniu materiałów i tworzeniu obiektów $\mathrm{z}$ modelowych danych $3 \mathrm{D}$, zazwyczaj warstwa po warstwie. Jest to przeciwieństwo obróbki ubytkowej, która polega na nadawaniu obiektowi konkretnych cech przez usuwanie nadmiaru materiału [Baumers et al. 2016: 193]. Technologie addytywne są utożsamiane z szybką obróbką i szybkim prototypowaniem, a w ostatnim czasie z szybkim wytwarzaniem, czyli drukowaniem 3D [Eyers, Potter 2017: 208]. W procesie rozwoju znajduje się już technologia druku 4D, w ramach której obiekty są drukowane w technologii 3D z inteligentnych materiałów, a następnie zmieniają swój kształt i mogą poruszać się w sposób imitujący procesy o charakterze naturalnym [Khoo et al. 2015: 104].

Technologie zakłócające (disruptive technologies) można zdefiniować w oparciu o dwa poziomy. Na pierwszym poziomie technologia zakłócająca zmienia sytuacje na ograniczonym do swojej specyfikacji rynku. Poziom drugi zakłócenia jest znacznie szerszy, obejmując swym zasięgiem obszar nie tylko właściwego sobie rynku, ale generuje wstrząsy społeczne, powodując zmiany w dużej skali [Schuelke-Leech 2018: 262].

Uwagi wymaga także fenomen działających w systemie międzynarodowym podmiotów niepaństwowych (non-state actors). Transformacja systemu międzynarodowego, zmiana realiów społecznych (individual empowerment) i gospodarczych, definiowana przez postęp procesów globalizacyjnych, skutkujących między innymi zmianą roli państw narodowych [Aleksandrowicz 2016: 42], spowodowała konsekwentny wzrost znaczenia tego typu uczestników stosunków międzynarodowych. Kategoria podmiotów niepaństwowych jest, ze względu na ich dużą różnorodność, trudna do zdefiniowania. Autor posłużył się definicją zaproponowaną przez Daphne Josselin i Williama Wallace'a [2001: 2-6], którzy nie traktują podmiotów niepaństwowych wyłącznie jako niezależnych od państw i sprawowanej przez nie władzy. Definiują je, akcentując źródła ich działania - społeczeństwo, gospodarkę lub procesy polityczne; sposób funkcjonowania - obecność w sieciach; wpływ na społeczeństwa więcej niż dwóch państw. Przyjmując tak szerokie podejście, do podmiotów niepan- 
stwowych można zaliczyć organizacje międzyrządowe, międzynarodowe organizacje pozarządowe, korporacje transnarodowe, zorganizowane grupy przestępcze oraz organizacje terrorystyczne.

Istotną z punktu widzenia przejrzystości wywodu oraz pozycji wyjściowej do jego przeprowadzenia jest kategoria słabych sygnałów (weak signals). Terminem tym określa się pierwsze symptomy zmiany, które mogą być rozumiane jako zaawansowane, ulokowane w określonym kontekście społecznym „wskaźniki zmiany w trendach i systemach, które konstytuują surowy materiał informacyjny, umożliwiający podjęcie prewencyjnych, przewidujących działań [...]. Reprezentują one pierwsze oznaki zmian paradygmatów, przyszłych trendów, sterowników lub braku ciągłości” [Saritas, Smith 2011: 297].

Analiza potencjalnych zakłóceń w systemie międzynarodowym, spowodowanym przez rozwój druku 3D, rozpocznie się od refleksji nad kwestiami ekonomicznymi, gdzie słabe sygnały rysują się coraz wyraźniej.

\section{ROZWÓJ DRUKU 3D A ŚWIATOWA GOSPODARKA}

Według raportu Internationale Nederlanden Groep [3D printing: a threat to global trade 2017: 8], rola tej technologii jest w tej chwili niewielka, jeśli porównywać ją do przemysłu tradycyjnego. Tradycyjna produkcja jest w dalszym ciągu tańsza, druk 3D jest wprowadzany w przemyśle wolno, a proces wytwarzania zbyt czasochłonny [Campbell et al. 2011: 11]. Analitycy ING prognozują jednak szybki rozwój technologii addytywnych, których rola w światowej gospodarce będzie rosła. Wartość inwestycji w technologię druku 3D zwiększa się w ostatnich latach w szybkim tempie. W roku 2016 druk 3D znalazł zastosowanie w produkcji lotniczej, motoryzacyjnej, medycznej oraz produkcji maszyn przemysłowych [3D printing: a threat to global trade 2017: 5]. Ocenia się, że druk 3D nie będzie wykorzystywany w sektorach, w których podstawą produkcji są surowce naturalne [Laplume, Petersen, Pearce 2016: 599-600]. Technologia ta jest stosowana głównie w Ameryce Północnej oraz Europie Zachodniej. Od kilku lat obserwuje się jednak rosnące inwestycje w druk 3D w Azji, przede wszystkim w Chinach [Gress, Kalafsky 2015: 44].

Druk 3D oferuje wiele korzyści, które stanowią o jego przewadze nad tradycyjną produkcją. Technologia ta umożliwia redukcję kosztów wytwarzania skomplikowanych elementów dzięki wykorzystaniu jednego urządzenia oraz skróceniu do minimum czasu produkcji i sprowadzeniu jej do jednego procesu. Zindywidualizowanie i modyfikacje produktu zgodnie z potrzebami odbiorcy są w tym świetle równie proste. Globalna skala produkcji przy użyciu druku 3D będzie łatwa do osiągnięcia, ponieważ projekty i wzory będą ,podróżować” w cyfrowej formie, przełamując barierę odległości, niwelując znaczenie czasu. Łańcuchy dostaw w formie znanej współcześnie przestaną istnieć [Barret 2014: 71-72]. Co warte uwagi, technologia druku 3D osiągnęła stadium, w którym pojedyncze urządzenie tego typu może 
samodzielnie wyprodukować niemal wszystkie części niezbędne do samoreplikacji [Johnston, Smith, Irwin 2018: 7].

Pytani przez analityków Rand Corporation eksperci ocenili, że druk 3D, działając jako technologia zakłócająca poziomu pierwszego, w największym stopniu wpłynie na sektor tradycyjnej produkcji i sektor materiałowy. W drugiej kolejności wymienia się sektory medyczny i farmaceutyczny, motoryzacyjny i transportowy, logistyczny oraz lotniczy i kosmiczny [Johnston, Smith, Irwin 2018: 9]. Druk 3D wywrze szczególny wpływ w dziedzinach, w których produkcja wymaga wielu etapów [3D printing: a threat to global trade 2017: 8]. Należy także zwrócić uwagę na wysokie prawdopodobieństwo skokowego rozwoju różnych, innowacyjnych (i być może tworzących kolejną warstwę zakłóceń) technologii „towarzyszących” [Mohr, Khan 2015: 23].

Potencjał tkwiący w druku 3D sprawia, że niemal powszechnie uznaje się go za nośnik niezwykle dużego potencjału wpływu na rzeczywistość międzynarodową. W orędziu o stanie państwa w 2013 ówczesny prezydent USA Barack Obama stwierdził, że druk 3D może ,zrewolucjonizować sposób w jaki wytwarzamy praktycznie wszystko" [Remarks by the President 2013]. Pytani przez analityków ING o opinie wysocy rangą menedżerowie, choć ostrożni w ocenach, także zgadzają się co do perspektyw rozwoju tej technologii. Lodewijk van der Borg, dyrektor generalny Kaak Group stwierdził, że w ciągu najbliższych jednej lub dwóch dekad około połowa całej produkcji będzie pochodzić z drukarek 3D [3D printing: a threat to global trade 2017: 7]. Cytowany L. van der Borg posłużył się perspektywą 10-20 lat. Uzasadniona będzie jednak refleksja w oparciu o odleglejszy horyzont czasowy. Zabieg ten pozwoli rozpatrywać dzisiejszy słaby sygnał jako technologię zakłócającą poziomu drugiego.

Analitycy ING [3D printing: a threat to global trade 2017: 11-12] szacują, że w 2060 roku, biorąc pod uwagę obecne tempo rozwoju technologii druku 3D, międzynarodowy handel towarami może się wyraźnie zmniejszyć. Wzorce wymiany handlowej ulegną więc zmianie, a wraz z nimi także model interakcji pomiędzy poszczególnymi elementami systemu międzynarodowego, a zatem także sposób jego funkcjonowania. Produkcja będzie w większym stopniu dostosowana do indywidualnych potrzeb konsumenta i będzie się odbywać znacznie bliżej odbiorcy końcowego. Tak samo rzecz ma się z częściami zamiennymi do bardziej skomplikowanych urządzeń. Produkcja będzie więc mogła szybko przestawiać się na towary o innej specyfikacji lub nawet całkiem nowe [Garret 2014: 72]. Zmniejszenie wymiany handlowej w skali świata to także zmiana struktury handlu usługami, np. magazynowania czy obsługi portowej. Ważniejsze staną się usługi zapewniające bezpieczeństwo transferu danych projektowych i ochrony własności intelektualnej [Rehhnberg, Ponte 2018: 69]. Zmniejszeniu ulegnie także międzynarodowy handel surowymi nieprzetworzonymi materiałami, potrzebnymi do produkcji, gdyż druk 3D będzie się opierał przede wszystkim na polimerach i metalach [Ngo et al. 2018: 172-173]. 
Przewiduje się, że druk 3D może spowodować przeniesienie produkcji z państw funkcjonujących obecnie jako „fabryki świata” [Garret 2014: 72]. Państwa te są miejscem lokowania produkcji ze względu na niskie koszty pracy. W perspektywie upowszechnienia się technologii druku 3D różnice w wynagrodzeniach dla siły roboczej (oraz jej wymaganych kompetencjach) zmienią się w sposób fundamentalny. Oznacza to, że produkcja wróci do krajów wysoko rozwiniętych. Obawiając się skutków, państwa te inwestują w druk 3D. Liderem są Chiny, które według niektórych ekspertyz mogą zdominować globalny rynek technologii addytywnych [Jennings 2018]. Ustanie konieczności lokowania produkcji poza własnymi granicami będzie wpływać na stopniową redukcję w deficytach handlowych państw wysoko rozwiniętych. Ze względu na powstały nowy model światowego handlu państwa wysoko rozwinięte wejdą na ścieżkę reindustrializacji [Dickel, Ferdinand, Petschow 2016: 20]. Wschodzące gospodarki będą z kolei zmuszone do strukturalnego dostosowania się do zmienionych warunków.

Jeśli rozwój technologii druku 3D będzie postępował (należy też wziąć pod uwagę jego gwałtowne przyspieszenie wywołane przełomem technologicznym), struktura światowej gospodarki ulegnie znacznemu przeobrażeniu. Siła ekonomiczna państw oraz firm nie będzie zależeć od rozbudowanej, konwencjonalnej infrastruktury produkcyjnej. $Z$ jednej strony, państwa rozwijające się stracą swój atut $\mathrm{w}$ postaci tańszej siły roboczej. $\mathrm{Z}$ drugiej, państwa o ugruntowanej pozycji gospodarczej zyskają możliwość zrównoważenia bilansu handlowego. Zmienią się obszary rywalizacji oraz kierunki rozwoju przedsiębiorstw. Działające globalnie firmy (oraz państwa) będą konkurować przede wszystkim o kontrolę nad sieciami podmiotów projektujących produkty [Jiang, Kleer, Piller 2017: 90]. Przedsiębiorstwa będą przy tym mogły działać bardziej elastycznie, gdyż będą w stanie testować bardzo wiele różnych prototypów oraz modeli biznesowych [Lipson, Kurman 2013: 56-57]. Zmianie ulegnie struktura zatrudnienia, co będzie stanowić wyzwanie dla systemów społecznych i politycznych. Rozwinięta technologia druku 3D będzie także ważną (choć nie jedyną) formą digitalizacji gospodarki i odchodzenia od tradycyjnego, materiałochłonnego modelu produkcji. Będzie to miało pozytywny wpływ na oddziaływanie produkcji na środowisko naturalne [Ford, Despeisse 2016: 574]. Druk 3D niewątpliwie wprowadzi wiele niezwykle użytecznych z punktu widzenia funkcjonowania człowieka innowacji [The State of 3D Printing 2018: 15]. Powstanie jednak konieczność redefinicji kwestii prawnych, standaryzacji, kontroli oraz bezpieczeństwa wykorzystania nowych technologii [Kietzmann, Pitt, Berthon 2015: 213]. Jest to szczególnie istotne z punktu widzenia kolejnych, coraz ważniejszych dla ludzkiego życia obszarów wykorzystania technologii addytywnych, np. przykład przemysłu biomedycznego. Kolejnym etapem ich rozwoju jest druk 4D i wykorzystanie inteligentnych materiałów, którego skutki są jeszcze trudniejsze do oszacowania [Papageorgiu 2017].

Jeśli państwa rozwijające nie zdołają się przygotować do potencjalnych zmian, ich gospodarki mogą wejść w fazę poważnych turbulencji, co może wywołać kaskadowe 
efekty społeczne, w tym także konflikty. Potencjalne, wieloskalowe kryzysy poszczególnych elementów ściśle powiązanego na wielu poziomach systemu międzynarodowego będą powodować reperkusje dla jego całości. Gospodarki, które nie opierają się na produkcji masowej, zyskają z kolei szanse na zwiększenie swojej roli na nowej mapie światowego handlu towarami oraz usługami. Wzrost ich znaczenia będzie się opierał na inwestycjach w najnowocześniejsze technologie, przede wszystkim know-how. Będzie to stanowiło kolejną ważną zmianę struktury systemu międzynarodowego.

Elementy podsystemu gospodarczego będą musiały zaadaptować się do nowej roli (trudno przewidzieć, w jakich warunkach, ponieważ rozwój druku 3D nie będzie przebiegał w próżni, lecz obok innych, potencjalnie zakłócających technologii). Współzależność i gęstość interakcji oraz sprzężeń w systemie międzynarodowym (które, jak można założyć, będą wzrastać wraz z rozwojem technologicznym) sprawi, że skutki rozwoju technologii będą odczuwalne na jego wszystkich poziomach. Rozpatrywana w ten sposób technologia druku 3D, w świetle teorii chaosu deterministycznego, odchyla trajektorię ewolucji (ruchu) systemu międzynarodowego (układu), który może okresowo tracić stabilność. Będzie się jednak poruszał dalej po fazach adaptacji do nowych warunków i osiągnięcia stanu równowagi.

Można zaryzykować stwierdzenie, że wstrząsy wywołane przez nową technologię zakłócającą działanie światowej gospodarki są naturalnym elementem długich cyklów. Efektom negatywnym towarzyszy wiele korzyści. Rozwój druku 3D może jednak oddziaływać na system międzynarodowy w sposób jednoznacznie negatywny. Chodzi o jego wykorzystanie do produkcji broni oraz w szerszym spektrum zastosowań wojskowych.

\section{TECHNOLOGIE ADDYTYWNE A KONFLIKTY MIĘDZYNARODOWE}

„Nadchodzi dzień, w którym będzie można wydrukować rakietę" - taki podtytuł nosi oficjalny komunikat koncernu zbrojeniowego Raytheon [To Print a Missile 2015], który prowadzi zaawansowane badania nad wykorzystaniem technologii addytywnych. „Uzbrojenie” technologii druku 3D posiada bardzo wysoki potencjał wpływu na to, jak będzie wyglądał charakter konfliktów przyszłości. Technologia ta będzie oczywiście jednym z czynników (obok sztucznej inteligencji, robotyki, nanotechnologii i innych) wpływu na ten wymiar funkcjonowania systemu międzynarodowego.

Rozpatrywanie technologii druku 3D w perspektywie szeroko rozumianego bezpieczeństwa odnosi się jednak w ostatnich latach przede wszystkim do kwestii łatwości konstruowania różnych typów broni ręcznej - od pistoletów po karabiny szturmowe. Efekt upowszechnienia takiej metody produkcji broni będzie stanowić wyzwanie dla władz państwowych w każdym zakątku świata.

W roku 2013 amerykański student prawa zaprezentował pistolet o nazwie Liberator, który został skonstruowany z wykorzystaniem plastikowych komponentów, wydrukowanych na wypożyczonej drukarce 3D. Jedyną częścią, która nie została 
wytworzona w ten sposób była iglica - użyto zwykłego gwoździa [Frey 2017: 21]. Prezentacja stała się bodźcem do ożywionej debaty w Stanach Zjednoczonych Ameryki, gdzie kwestia wolnego dostępu do broni budzi szczególnie wiele emocji. Projekty broni zostały umieszczone w sieci, co w atmosferze kontrowersji zostało zabronione przez amerykański sąd federalny [3D-printed gun 2018]. Kwestia ta z pewnością będzie przedmiotem sporu o to, czy upowszechnianie projektów broni w internecie spełnia kryteria definicji zagrożenia dla bezpieczeństwa. Trend ten w dłuższej perspektywie z pewnością będzie oddziaływał na sytuację międzynarodową. Jeśli dostęp do tego typu technologii oraz użyczonych publicznie planów będą mieli zwykli obywatele każdego państwa na świecie, będą nim dysponować także zorganizowane grupy przestępcze oraz organizacje terrorystyczne.

Ma to szczególne znaczenie dla funkcjonowania systemu międzynarodowego. Wytwarzanie broni ręcznej to nie jedyna, choć podstawowa manifestacja tego problemu. Co zrozumiałe, ułatwienie dostępu do środków bojowych dla odwołujących się do przemocy podmiotów niepaństwowych będzie wywierać presje na poszczególne elementy systemu międzynarodowego. Odnosi się to nie tylko do działających globalnie organizacji, takich jak Daesh i jego zlokalizowane w wielu częściach świata struktury czy Al-Kaida, ale także mniejszych grup lub tzw. samotnych wilków (jak Anders Breivik). Możliwe będzie uniknięcie wykrycia plastikowej broni przez ochronę ważnych osób lub obiektów lub wyprodukowanie urządzenia wybuchowego doskonale imitującego przedmioty codziennego użytku. Dodaje to istotny element niepewności związany z działaniami anty- i kontrterrorystycznymi.

Problem rozwoju technologii tego typu nie ogranicza się jednak do i tak stosunkowo łatwo dostępnej broni ręcznej. Upowszechnienie technologii addytywnych oraz know-how w postaci gotowych wzorów i dostępnych online projektów otwiera, przede wszystkim przed organizacjami terrorystycznymi, szerokie spektrum możliwości. Nie jest to jedynie kwestia masowej produkcji broni, ale także części, z których mogą one konstruować bezzałogowe statki powietrzne, które z kolei mogą znaleźć różne zastosowania $\mathrm{w}$ działaniach przeciwko celom wojskowym i cywilnym. Rozprzestrzenianie się druku 3D sprawi, że organizacje tego typu będą mogły wyprodukować różnego rodzaju broń na terenie państwa-celu. Produkcja części do bardziej zaawansowanych systemów uzbrojenia będzie w zasięgu tego typu grup. Zwiększą się także możliwości produkcji nielegalnych dóbr, które będą niezwykle cennym towarem na czarnym rynku, co pozytywnie wpłynie na bazę finansowania dla organizacji tego rodzaju. Biorąc pod uwagę możliwości technologii addytywnych i wysokie zdolności adaptacyjne oraz kreatywność [Grillo 2015] tych działających w oparciu o strukturę sieciową organizacji, można się spodziewać różnego rodzaju nowych i zaskakujących rozwiązań technicznych w ramach arsenału działań asymetrycznych. Według ekspertyzy Rand Corporation, nowe zdolności organizacji terrorystycznych i przestępczych utrudnią strukturom bezpieczeństwa śledzenie i wykrywanie ich działań, polegające w dużej mierze na rozpoznawaniu szlaków dostaw broni [Johnston, Smith, Irwin 2018: 14]. 
Reasumując, niepaństwowe organizacje o charakterze zbrojnym rozszerzą możliwości swojego działania, przez co zagrożenie z ich strony może znacząco wzrosnąć, a w niektórych obszarach zmienić swój charakter. Wspomniana trudność w śledzeniu organizacji, takich jak Deash, Al-Kaida, włoskie grupy mafijne, kartele narkotykowe w rodzaju Los Zetas czy gangów, jak MS-13, sprawi, że ich nowe możliwości będą poznawane po efektach, np. zamachach terrorystycznych. Działalność terrorystyczna lub przestępcza zyska nowy wymiar, co będzie wymuszać na poszczególnych elementach systemu międzynarodowego dostosowanie, podobnie jak stało się to po zamachach z 11 września 2001 roku. Druk 3D zakłóci w ten sposób działanie systemu, który w większym lub mniejszym stopniu zdołał się przez lata dostosować do nowego modus operandi grup terrorystycznych i przestępczych.

Rozwój druku 3D będzie miał także znaczenie dla potencjałów militarnych wszystkich państw, które cały czas pozostają jednym z najważniejszych elementów systemu międzynarodowego. Ich struktury wojskowe już teraz wykorzystują drukarki 3D. Korpus Piechoty Morskiej USA wyprodukował w około 40 godzin za pomocą drukarki 3D prototyp baraku dla żołnierzy [Mizokami 2018]. Plany amerykańskiego wojska w kwestii zastosowania druku 3D w wielu aspektach, także bojowych, są cały czas rozwijane [Baker 2018]. Chińska marynarka wojenna umieściła na swoich okrętach drukarki 3D do produkcji części zamiennych [Anderson Goehrke 2015]. Armia brytyjska wykorzystuje drukarki 3D w ramach misji ONZ w Sudanie Południowym [Jackson 2018], a Bundeswehra w Afganistanie [German army uses $3 D$ printers 2019].

Jak pokazują przywołane wyżej przykłady, druk 3D znacząco zmieni logistykę operacji ekspedycyjnych. Działające daleko poza granicami macierzystego kraju jednostki wojskowe będą $\mathrm{w}$ większym stopniu samowystarczalne, co z pewnością wpłynie na ich profil operacyjny. W dłuższej perspektywie, kiedy rozwinięte zostaną technologie bojowych zastosowań technologii addytywnych (obok innych zdobyczy czwartej rewolucji przemysłowej), zmieni się charakter wykorzystywania siły wojskowej w konfliktach. Obserwowana współcześnie zmiana paradygmatu ${ }^{10}$ prowadzenia działań zbrojnych będzie przybierać kolejne formy (należy podkreślić nieliniowość tego procesu), co wywoła także zmiany w zachowaniu państw w konfliktach, charakter i zakres ewentualnego zaangażowania, model i strukturę sił zbrojnych, ich misje i zadania, odbiór i pozycję społeczną itp. Można przewidywać, że siły zbrojne będą stawać się do tego stopnia autonomiczne, iż redukcji ulegnie ich całe otoczenie - od przedsiębiorstw zbrojeniowych po różnego rodzaju zewnętrznych usługodawców.

Podobnie jak w przypadku zmian ekonomicznych, które w dłuższej perspektywie doprowadzą do wyłonienia się nowego modelu rozkładu sił w światowej gospodarce i otworzą drogę małym państwom o relatywnie niskim potencjale demograficznym

${ }^{10}$ Coraz częstsze używanie bezzałogowych statków powietrznych konsekwentnie zmienia charakter sił powietrznych. 
i przemysłowym, posiadającym wysokie zdolności militarne. Za wymowny przykład może posłużyć rozważane od wielu lat masowe wykorzystanie roju (swarm) wytworzonych w technologii 3D dronów, które przy prognozowanej jako wysoka skuteczności charakteryzują się niską ceną [Graber 2014]. Obserwowane w ostatnich latach coraz szersze użycie operujących samodzielnie i ilościowo niewielkich pododdziałów sił specjalnych ulegnie kolejnym modyfikacjom i pozwoli względnie słabym państwom posiadać siłę militarną na wysokim poziomie. Zmieni to model dystrybucji klasycznej siły w systemie międzynarodowym (trzeba tu brać pod uwagę także opisane wyżej podmioty niepaństwowe).

Należy także zwrócić uwagę na kwestię różnego rodzaju sankcji, ważnego instrumentu wykorzystywanego w systemie międzynarodowym przeciwko państwom łamiącym normy prawne, szczególnie w zakresie wojskowego wykorzystania technologii nuklearnej. Jak wynika z analizy, drukarka 3D jest niemal idealnym przykładem urządzenia podwójnego przeznaczenia. Zainteresowane rozwojem broni atomowej państwo będzie więc mogło wiele komponentów wyprodukować samodzielnie, omijając międzynarodowe reżimy kontrolne [Kroenig, Volpe 2015: 10-11], pozyskując projekty przy zastosowaniu ofensywnych instrumentów wywiadowczych, osobowych (HUMINT) czy elektronicznych (ELINT).

System międzynarodowy będzie zatem musiał, po przejściu faz wstrząsów, wracając na tory relatywnie stabilnego funkcjonowania, dostosować się do nowych potencjałów, możliwości i celów oraz wzorców zachowań, które zmodyfikują charakter interakcji między jego elementami. Rozwój druku 3D stworzy nowe osie konfliktów, zmodyfikuje sposoby użycia siły militarnej oraz wpłynie na jeszcze większą nieprzewidywalność zachowań aktorów niepaństwowych.

\section{ZAKOŃCZENIE}

Potencjalne zmiany w systemie międzynarodowym, wywołane rozwojem technologii druku 3D należy rozpatrywać jako ściśle powiązane, często kaskadowe procesy, które dotkną wielu płaszczyzn funkcjonowania poszczególnych jego elementów. Technologie addytywne rozwijają się dynamicznie, a ze względu na swój potencjał zakłócający są szeroko dyskutowane. Pojawia się wiele głosów o tym, że obawy przed jej rozpowszechnieniem są zdecydowanie nieproporcjonalne [Lopez 2018]. Zarys jego możliwych skutków, przedstawiony w niniejszym artykule wskazuje jednak, że niepewność związana z drukiem 3D jest w dużym stopniu uzasadniona.

W pełni rozwinięte technologie addytywne zakłócą funkcjonowanie systemu międzynarodowego po wyjściu poza rynki, na których zaistnieją. Jego upowszechnienie zmieni strukturę światowej gospodarki, w dłuższej perspektywie redukując wymianę handlową ze względu na rosnącą bliskość ośrodków produkcji i odbiorcy końcowego. Będzie to stanowić kolejny sterownik przenoszenia się światowego handlu w kierunku domeny cyfrowej - jego osią będzie transfer projektów, matryc, 
na bazie których będzie odbywać się produkcja. Ochronie będzie podlegać ta właśnie sfera, a w coraz mniejszym stopniu istotne będzie bezpieczeństwo kontenerowców na szlakach oceanicznych. Zmiany w strukturze światowego handlu spowodują problemy dla gospodarek opartych na taniej sile roboczej. Strategiczna prognoza Narodowej Rady Wywiadu USA wskazuje w tym kontekście na Afrykę [Global Trends 2017: 40]. Państwa rozwijające się mogą wobec powyższego znacznie ucierpieć ze względu na wstrząsy społeczne, prawdopodobne wybuchy przemocy i podatność na radykalne idee. Implozja niektórych państw spowoduje destabilizację regionów, wpływając tym samym na cały system międzynarodowy. W światowej gospodarce pojawią się tymczasem nowe ośrodki, które nie będąc uzależnione od siły roboczej, staną się w większym stopniu samodzielne, a na jej całość będą oddziaływać dzięki know-how oraz długoletnim inwestycjom w nowe technologie.

Trudno spodziewać się zakończenia większości zadawnionych, geopolitycznie czy religijnie zdeterminowanych konfliktów. Rozwój druku 3D może jednak zmienić modus operandi aktorów w nich uczestniczących. Odnosi się to do nowych instrumentów, które znajdą się w rękach działających globalnie organizacji terrorystycznych, transnarodowych grup przestępczych, ale także w coraz większym stopniu upodmiotowionych (w przypadku radykalizacji niebezpiecznych) jednostek. Rywalizacja „tarczy i miecza” doprowadzi z pewnością do powstania nowych środków obrony. Można jednak założyć, że manifestacje nowych sposobów działań terrorystycznych świat pozna po kolejnych atakach.

Zmiany, których symptomy są już widoczne, obejmą także strukturę sił i środków oraz metody działania sił zbrojnych. Technologia 3D wspomoże operacje ekspedycyjne na dalekich dystansach, uprości logistykę działań, zautonomizuje nasycone innymi wysokimi technologiami jednostki wojskowe i wpłynie na charakter konfliktów. Odnosi się to nie tylko do klasycznych wojen między suwerennymi państwami, ale także, a może przede wszystkim, do konfliktów hybrydowych, znajdujących się poniżej progu wojny. Rosnąca intensywność globalnej rywalizacji między dotychczasowym hegemonem Stanami Zjednoczonymi a państwem, które, na co wskazuje większość oznak, rzuciło im wyzwanie - Chinami, nie osiągnęła jeszcze swojego apogeum. Kiedy to jednak nastąpi, ewentualny otwarty konflikty między potęgami i towarzyszące mu konflikty peryferyjne mogą przyjąć zupełnie inny charakter ze względu na rozwój technologiczny [zob. Cole, Singer 2017; Allison 2018].

Podobnie jak w przypadku gospodarki w systemie międzynarodowym pojawią się nowe ośrodki siły, których asertywność będzie proporcjonalna do definiowanej przez technologię siły, która zdeterminuje ich konkretne zachowania. Można żywić obawy, że wschodzące centra w wielobiegunowym świecie, dzięki technologiom addytywnym, będą miały ułatwioną drogę do pozyskania broni masowego rażenia, $\mathrm{w}$ tym broni jądrowej poza reżimami międzynarodowymi.

Suma tych zmian zmodyfikuje mechanizmy działania systemu międzynarodowego. Zgodnie z teorią chaosu nastąpią wstrząsy i kryzysy, generowane przez nieliniowość jego ruchu. Według niektórych druk 3D całkowicie zmieni świat. Horyzont 
tych prognoz, ze względu na to, że technologia ta w dalszym ciągu może uchodzić za słaby sygnał nadchodzących zmian, jest niezwykle długi, sięga dekad (Rand Corporation - 2040 roku; ING - 2060). Potencjał, którego jest ona nośnikiem, jest jednak na tyle poważny, że refleksja nad negatywnymi skutkami jego rozwoju jest w pełni uzasadniona.

Należy mieć świadomość, że zakłócenia wywołane przez rozwój technologii addytywnych są jedną z wielu kierunków zmian. Transformacje te, podobnie jak natura druku 3D będą zbudowane z wielu warstw, definiowanych przez technologie składające się na tzw. czwartą rewolucję przemysłową.

\section{BIBLIOGRAFIA}

3D printing: a threat to global trade. 2017. ING, https://www.ingwb.com/media/2088633/3d-printing-report-031017.pdf (dostęp: 07.02.2019).

3D-printed gun blueprints ban extended. 2018. https://www.bbc.com/news/technology-45328960 (dostęp: 14.02.2019).

Agomouh, F. 2018. Sztuczna inteligencja w telefonach i funkcje, z których będziemy dzięki niej korzystać, https://businessinsider.com.pl/technologie/nowe-technologie/sztuczna-inteligencja-wykorzystanie-w -smartfonach-jak-pomoze/0p2b7hx (dostęp: 01.12.2018).

Aleksandrowicz, T.R. 2016. Podstawy walki informacyjnej, Editions-Spotkania, Warszawa.

Allison, G. 2018. Skazani na wojnę? Czy Ameryka i Chiny unikna pułapki Tukidydesa, Pascal, Bielsko-Biała. Alpaydin, E. 2016. Machine Learning: The New AI, MIt Press, London.

André, J.C. 2018. From additive manufacturing to 3D/4D printing 3 Breakthrough Innovations: Programmable Material, 4D Printing and Bio-printing, Iste Ltd and John Wiley \& Sons, Inc., London.

Baker, B. 2018. Made to measure: the next generation of military $3 D$ printing, https://www.army-technology. com/features/made-measure-next-generation-military-3d-printing/ (dostęp: 19.02.2019).

Barnatt, C. 2013. 3D Printing: The Next Industrial Revolution, expalining the Future, North Charleston, SC.

Baumers, M, Dickens, P., Tuck, C., Hague, R. 2016. The cost of additive manufacturing: machine productivity, economies of scale and technology-push, "Technological Forecast \& Social Change", nr 102. DOI: $10.1016 /$ j.techfore.2015.02.015.

Beck, U. 2008. World at Risk. The New Task of Critical Theory, "Development and Society", vol. 27, no. 1.

Beck, U. 2012. Spoteczeństwo światowego ryzyka. W poszukiwaniu utraconego bezpieczeństwa, Wydawnictwo Naukowe Scholar, Warszawa.

Bostrom, N. 2016. Superintelligence: Paths, Dangers, Strategies, Oxford University Press, Oxford.

Campbell, T., Williams, C., Ivanova, O., Garrett, B. 2011. Could 3D Printing Change the World? Technologies, Potential, and Implications of Additive Manufacturing, Atlantic Council, Washington, D.C.

Chodubski, A. 2009. Prognostyka jako wyzwanie metodologiczne w badaniu stosunków międzynarodowych, „Annales Universitatis Mariae Curie-Skłodowska” vol. XVI, nr 2, s. 46.

Choucri, N. 1974. Forecasting in International Relations: Problems and Prospects, "International Interactions", nr 1. DOI: https://doi.org/10.1080/03050627408434390.

Cole, A., Singer, P.W. 2017. Ghost Fleet. Następna wojna światowa, Bellona, Warszawa.

Costandi, M. 2016. Neuroplasticity, MIt Press, London.

Culey, S.A. 2018. Transition Point: From Steam to the Singularity, Troubador Publishing, New York.

Cukier, L., Mayer-Shonberger, V. 2017. BIG DATA - efektywna analiza danych .

Rewolucja, która zmieni nasze myślenie, pracę i życie, Mt Biznes, Warszawa.

Czerwiński, K., Czerwiński, M. 2015. Drukowanie w 3D, InfoAudit, Warszawa. 
D’Aveni, R. 2018. The Pan-Industrial Revolution: How New Manufacturing Titans Will Transform the World, Houghton Mifflin Harcourt, New York.

Daly, A. 2017. Socio-Legal Aspects of the 3D Printing Revolution, Palgrave Macmillan, New York.

Dickel, S., Ferdinand, J.-P., Petschow, U. 2016. The Multiple Applications of 3D Printing: Between Maker Movements and the Future of Manufacturing, [w:] The Decentralized and Networked Future of Value Creation. 3D Printing and its Implications for Society, Industry, and Sustainable Development, J.-P. Ferdinand, U. Petschow, S. Dickel (red.), Springer International Publishing, Cham.

Design Anthropological Futures. 2016. R.C. Smith, K.T. Vangkilde, M.G. Kjærsgaard, T. Otto, J. Halse, T. Binder (red.), Bloomsbury Publishing, Bloomsbury Publishing, London.

Domingos, P. 2016. Naczelny algorytm. Jak jego odkrycie zmieni świat, Helion, Warszawa.

Doran, C.F. 1999. Why forecasts fail? The Limits And Potential of Forecasting in International Relations and Economics, "International Studies Review", vol. 1, no. 2.

Eyers, D. R., Potter, A. T. 2017. Industrial Additive Manufacturing: A manufacturing systems perspective, "Computers in Industry", nr 92-93. DOI: 10.1016/j.compind.2017.08.002.

Fey, M. 2017. 3D printing and international security: risks and challenges of an emerging technology (PRIF Reports, 144). Frankfurt am Main: Hessische Stiftung Friedens- und Konfliktforschung, http:// nbn-resolving.de/urn:nbn:de:0168-ssoar-51867-8 (dostęp: 14.02.2019).

Ford, M. 2016. Rise of the Robots: Technology and the Threat of a Jobless Future, Basic Books, New York.

Ford, S., Despeisse, M. 2016. Additive manufacturing and sustainability: an exploratory study of the advantages and challenges, "Journal of Cleaner Production", vol. 137. DOI: http://dx.doi.org/10.1016/j. jclepro.2016.04.150.

Gabor, D. 1964. Invtenting Future, Pengiun Books, London.

Garret, B. 2014. 3D Printing: New Economic Paradigms and Strategic Shifts, "Global Policy” vol. 5, issue 1. DOI: $10.1111 / 1758-5899.12119$.

German army uses 3D printers to produce spare parts in operations. 2019, https://www.armyrecognition. com/weapons_defence_industry_military_technology_uk/3d_printers_at_the_rescue_in_operations. html (dostęp: 17.02.2019).

Gibson, I., Rosen, D., Stucker, B. 2015. Additive Manufacturing Technologies: 3D Printing, Rapid Prototyping, and Direct Digital Manufacturing, Springer, New York.

Gleick, J. 2018. Chaos. Narodziny nowej nauki, Wydawnictwo Zysk i S-ka, Poznań.

Global Trends: Paradox of Progress. 2017. U.S. National Intelligence Council, Washington, D.C.

Goehrke Anderson, S. 2015. China's PLA Navy Deploys 3D Printers Onboard Warships to Replace Small Parts, https://3dprint.com/35981/china-pla-navy-3d-printing/ (dostęp: 17.02.2019).

Graber, J. 2014. Swarms of 3d Printed Drones May Be the Future Of Combat, http://www.3dprinterworld. com/article/swarms-3d-printed-drones-may-be-future-combat (dostęp: 19.02.2019).

Greengard, S. 2015. The Internet of Things, MIt Press, London.

Gress, D. R., Kalafsky, R.V. 2015. Geographies of production in 3D: Theoretical and research implications stemming from additive manufacturing, "Geoforum", vol. 60. DOI: 10.1016/j.geoforum.2015.01.003.

Grillo, I. 2015. Mexican Cartels Invent Ingenious Weapons to Help Battle Government, http://time. com/3839774/cartels-mexico-ingenious-weapons/ (dostęp: 17.02.2019).

Gruszko, K., Gajewski, T. 2018. Regress of The West and the Emerging of New World Order: The Case of NATO, "Athenaeum. Polskie Studia Politologiczne”, vol. 60. DOI: 10.15804/Athena.2018.60.11.

Hanson, E.C. 2008. The Information Revolution and World Politics, Rowman \& Littlefield Publishers, New York.

Harrari, Y.N. 2018. Homo deus. Krótka historia jutra, Wydawnictwo Literackie, Kraków.

Hornick, J. 2015. 3D Printing Will Rock the World, North Charleston.

Jackson, B. 2018. British Army Applies Lulzbot 3d Printers to Peacekeeping in South Sudan, https://3dprintingindustry.com/news/british-army-applies-lulzbot-3d-printers-to-peacekeeping-in-south-sudan-145492/ (dostęp: 19.02.2019).

James, R. C. 2014. Science Unshackled, John Hopkins University Press, Baltimore. 
Jennings, R. 2018. China Lays Groundwork For Asian, World Lead In 3D Printing, https://www.forbes.com/ sites/ralphjennings/2018/02/01/china-lays-groundwork-for-asian-world-lead-in-3d-printing/\#5eeae3dd7f54 (dostęp: 09.02.2019).

Jervis, R. 1997. System Effects. Complexity in Political and Social Life, Princeton University Press, Princeton, NJ.

Jiang, R., Kleer, R., Piller, F. T. 2017. Predicting the future of additive manufacturing: A Delphi study on economic and societal implications of $3 D$ printing for 2030, "Technological Forecasting \& Social Change" vol. 119. DOI: 10.1016/j.techfore.2017.01.006.

Johnston, T., Smith, T. D., Irwin, J. L. 2018. Addidtive Manufacturing in 2040. Powerful Enabler, Disruptive threat, Rand Corporation, Santa Monica.

Jordan, M.J. 2016. Robots, MIt Press, London.

Josselin, D., Wallace, W. 2001. Non-state Actors in World Politics: a Framework, [w:] Non-state Actors in World Politics, D. Josselin, W. Wallace (red.), Palgrave Publishers, New York.

Kaku, M. 2011. Fizyka przyszłości. Nauka do 2100 roku, Prószyński Media, Warszawa.

Kaku, M. 2014. Przyszłość umystu, Prószyński Media, Warszawa.

Karpiński, A. 2009. Co trzeba wiedzieć o studiach nad przyszłościa? Polskie Towarzystwo Ekonomiczne, Warszawa.

Khoo, Z.X., Mei, J.E., Teoh, L.Y, Kai Chua, C., Yang, S., An, J., Leong, K.F., Yeong, W.Y. 2015. 3D printing of smart materials: A review on recent progresses in $4 D$ printing, "Virtual and Physical Prototyping", vol. 110, no. 3. DOI: https://doi.org/10.1080/17452759.2015.1097054.

Kietzmann, J., Pitt, L., Berthon, P. 2015. Disruptions, decisions, and destinations: Enter the age of 3-D printing and additive manufacturing, "Business Horizons" vol. 58. DOI: 10.1016/j.bushor.2014.11.005.

Kissane, D. 2007. A Chaotic Theory of International Relations? The Possibility for Theoretical Revolution in International Politics, "Pro Polis", nr 2.

Kozub, M. 2013. Myśleć strategicznie o bezpieczeństwie przyszłości, Akademia Obrony Narodowej, Warszawa.

Kozubek, J. 2018. Modern Prometheus: Editing the Human Genome with Crispr-Cas9, Cambridge University Press, New York.

Kroenig, M., Volpe, T. 2015, 3-D Printing the Bomb? The Nuclear Nonproliferation Challenge, "The Washington Quarterly", vol. 38 no. 3. DOI: 10.1080/0163660X.2015.1099022.

Kurzweil, R. 2006. The Singularity Is Near: When Humans Transcend Biology, Penguin Books, New York.

Laplume, A. O., Beterse, M., Pearce J. M. 2016. Global value chains from a 3D printing perspective, "Journal of International Business Studies", vol. 47, issue 5. DOI: 10.1057/jibs.2015.47.

Latiff, R.H. 2018. Wojna przyszłości. W obliczu nowego globalnego pola bitwy, Wydawnictwo Naukowe PWN, Warszawa.

Lipson, H., Kurman, M. 2013. Fabricated: The New World of 3D Printing, John Wiley \& Sons, Inc., Indianapolis, IN.

Lopez, E. 2018. Not just hype: 3-D printing expected to transform global industries, https://www.supplychaindive.com/news/3D-printing-hype-GE-Innovation-Barometer-report/517364/ (dostęp: 19.02.2019).

Łoś-Nowak, T. 1993. Funkcja predyktywna nauki o stosunkach międzynarodowych. Wyzwania i zagrożenia, „Studia Polityczne”, nr 1-4 (5).

Łoś-Nowak, T. 2006. Stosunki międzynarodowe. Teorie - systemy - uczestnicy, Wydawnictwo Uniwersytetu Wrocławskiego, Wrocław.

McIntyre, J.J. 2013. Chaos Theory, [w:] Encyclopedia of Crisis Management, K.B. Penuel, M. Statler, R. Hagen (red.), Sage Publishing, London.

Mizokami, K. 2018. The Marines 3D Printed a Concrete Barracks, https://www.popularmechanics.com/ military/research/a22877745/the-marines-3d-printed-a-concrete-barracks/ (dostęp: 17.02.2019).

Mohr, S., Khan, O. 2015. 3D Printing and Its Disruptive Impacts on Supply Chains of the Future, "Technology Innovation Management Review", vol. 5, issue 11.

DOI: https://doi.org/10.22215/timreview/942. 
Ngo, T. D., Kashani, A., Imbalzano, G., Nguyen, K., Hui, D. 2018. Additive manufacturing (3D printing): A review of materials, methods, applications and challenges, „Composites Part B: Engineering”, vol. 143. DOI: 10.1016/j.compositesb.2018.02.012.

Nowina-Konopka, M. 2017. Infomorfoza. Zarzadzanie informacja w nowych mediach, Wydawnictwo Uniwersytetu Jagiellońskiego, Kraków.

O’Neill, C. 2018. Broń matematycznej zagłady. Jak algorytmy zwiększaja nierówności i zagrażaja demokracji, Wydawnictwo Naukowe PWN, Warszawa.

Osterhammel, J. 2013. Historia XIX wieku. Przeobrażenie świata, Wydawnictwo Poznańskie, Poznań.

Papageorgiu, M. 2017. 4D Printing: A technology coming from the future, https://www.sculpteo.com/ blog/2017/10/25/4d-printing-a-technology-coming-from-the-future/ (dostęp: 10.02.2019).

Parrington, J. 2016. Redesigning Life: How genome editing will transform the world, Oxford University Press, Oxford.

Pasquale, F. 2016. The Black Box Society: The Secret Algorithms That Control Money and Information, Harvard University Press, New York.

Payne, K. 2018. Strategy, Evolution, and War: From Apes to Artificial Intelligence, Georgetown University Press, Washington, D.C.

Paus, E. 2018. Confronting Dystopia: The New Technological Revolution and the Future of Work, Cornell University Press, New York.

Randers, J. 2014. Rok 2052. Globalna prognoza na najbliższe czterdzieści lat, Dom Wydawniczy Elipsa, Warszawa.

Rehnberg, M., Ponte, S. 2018. From smiling to smirking? 3D printing, upgrading and the restructuring of global value chains, "Global Networks. A Journal of Transnational Affairs", vol. 18, issue 1. DOI: 10.1111/glob.12166.

Remarks by the President in the State of the Union Address. 2013.o, https://obamawhitehouse.archives.gov/ the-press-office/2013/02/12/remarks-president-state-union-address (dostęp: 09.02.2019).

Ross, A. 2017. The Industries of the Future, Simon \& Schuster, New York.

Rundle, G. 2014. A Revolution in the Making: 3D Printing, Robots and the Future, Affirm Press, Melbourne.

Ruppel Shell, E. 2018. The Job: Work and Its Future in a Time of Radical Change, Random House, New York.

Saffo, P. 2007. Six Rules for Effective Forecasting, "Harvard Business Review", nr 60.

Sajduk, B. 2010. Czy w nauce o stosunkach międzynarodowych możliwe jest efektywne prognozowanie?, https://www.researchgate.net/publication/259646504_Czy_w_nauce_o_stosunkach_miedzynarodowych_mozliwe_jest_efektywne_prognozowanie (dostęp: 02.02.2019).

Saritas, O., Smith, J. E. 2011. The Big Picture - trends, drivers, wild cards, discontinuities and weak signals, "Futures", t. 43, nr 3, DOI: https://doi.org/10.1016/j.futures.2010.11.007.

Schlak, M. 2015. Industrie 4.0 Was die Roboter der Zukunft können, http://www.spiegel.de/wirtschaft/ unternehmen/hannover-messe-industrie-4-0-und-internet-der-dinge-a-1027553.html (dostęp: 29.03.2018).

Schwab, K. 2016. The Fourth Industrial Revolution, Penguin Books, London.

Schuelke-Leech, B-A. 2018. A model for understanding the orders of magnitude of disruptive technologies, "Technological Forecasting \& Social Change", nr 129. DOI: 10.1016/j.techfore.2017.09.033.

Schwab, K. 2016. The Fourth Industrial Revolution, Portfolio Penguin, London.

Shanahan, M. 2015. The Technological Singularity, MIt Press, London.

Sharre, P. 2018. Army of None: Autonomous Weapons and the Future of War, WW Norton, New York.

Siemiński, P., Budzik, G. 2015. Techniki przyrostowe: druk, drukarki 3D, Oficyna Wydawnicza Politechniki Warszawskiej.

Skilton, M., Hovsepian, F. 2017. The 4th Industrial Revolution: Responding to the Impact of Artificial Intelligence on Business, Palgrave Macmillan, New York.

Springer, P.J. 2018. Outsourcing War to Machines. The Military Robotics Revolution, Praeger security International, Santa Barbara. 
Sułek, M. 2010. Prognozowanie i symulacje międzynarodowe, Wydawnictwo Naukowe Scholar, Warszawa. Tegmark, M. 2017. Life 3.0: Being Human in the Age of Artificial Intelligence, Random House, New York. The Decentralized and Networked Future of Value Creation: 3D Printing and its Implications for Society, Industry, and Sustainable Development. 2016. J.P. Ferdinand, U. Petschow, S. Dickel (red). Springer, Basel.

The State of 3D Printing. 2018, https://www.sculpteo.com/media/ebook/State_of_3DP_2018.pdf(dostęp: 10.02.2019).

To Print a Missile. Raytheon research points to 3-D printing for tomorrow's technology. 2015, https://www. raytheon.com/news/feature/print-missile (dostęp: 13.02.2019).

Tønnessen, T. H. 2017. Islamic State and Technology - A Literature Review, "Perspectives on Terrorism", vol. 11 no. 3.

Walsh, T. 2018. To żyje! Sztuczna inteligencja. Od logicznego fortepianu po zabójcze roboty, Wydawnictwo Naukowe PWN, Warszawa.

Waltz, K. H. 2010. Struktura teorii stosunków międzynarodowych, Wydawnictwo Naukowe Scholar, Warszawa.

Winnan, C.D. 2013. 3D Printing: The Next Technology Gold Rush - Future Factories and How to Capitalize on Distributed Manufacturing, Create Space Independent Publishing Platform North Charleston, SC.

\section{DD PRINTING AS A DISRUPTIVE TECHNOLOGY IN THE INTERNATIONAL SYSTEM}

Abstract: Rapid technological development increasingly defines activities of individuals, societies and nation states. Its pace is high, and it causes problems in social absorption of its already visible effects as well as anxiety about their influence in the future. 3D printing technology is one of the significant manifestations of technological development. The purpose of the paper is to outline its possible effect on international system in the future.

The analysis starts with a short introduction, supplemented by an overview of Polish and international literature, concerning 3D printing technology. Then, the author outlines a methodology and formulates hypotheses and research questions. This section is followed by the conceptual framework with crucial categories and their definitions. In the next section, the author verifies the hypotheses and presents possible economic consequences of 3D printing development and its influence on the structure of international conflicts, which creates a picture of the probable impact on the international system as a whole.

Keywords: 3D printing, international system, disruptive technology, international forecasting, global economy, international security

\section{BIOGRAM}

Tomasz Gajewski, politolog, doktor nauk humanistycznych, adiunkt, zastępca dyrektora Instytutu Stosunków Międzynarodowych i Polityk Publicznych na Uniwersytecie Jana Kochanowskiego w Kielcach. Specjalizuje się w prognozowaniu międzynarodowym oraz studiach nad wpływem postępu technologicznego (przede wszystkim technologii informacyjnych) i zmian klimatu na stabilność systemu międzynarodowego oraz parametry strategicznego środowiska bezpieczeństwa. Członek Polskiego Towarzystwa Nauk Politycznych i Analityk w Fundacji Po.Int, publicysta w Nowej Konfederacji. Kontakt e-mail: tomasz.gajewski@ujk.edu.pl. 